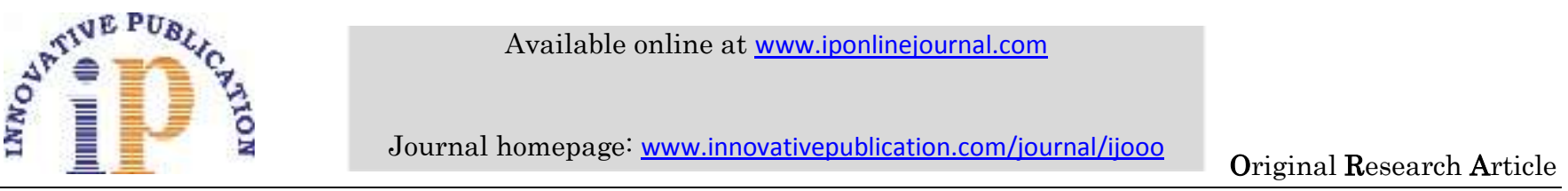

\title{
Prevalence of ocular injuries in a tertiary care hospital
}

\author{
Anuradha $^{1}$, Sheetal $^{2 *}$ \\ ${ }^{\mathbf{1}}$ Associate Professor, ${ }^{2}$ Junior Resident, Dept. of Ophthalmology, Saveetha Medical College, Chennai, Tamil Nadu, India
}

\begin{abstract}
Aim and Objective: To study and analyse the profile of ocular injuries presenting to our hospital.

Materials and Methods: A hospital based observational prospective study was conducted from January 2018 to January 2019. Data on demographics, nature and severity of injury, visual acuity at the time of presentation and during follow up were noted. A thorough evaluation included visual acuity, colour vision, anterior and posterior segment examination and imaging whenever needed was done. The patient was followed for three months and the best corrected visual acuity at the end of 12 weeks was recorded.

Results: A total of 240 patients were recorded of whom males outnumbered the females and children and constituted 63\%(151) of people involved. Most common cause being RTA occurred that in the age group 21-30 years. With maximum number of accidents from twowheeler followed by industrial injuries. Injuries involving anterior segment constituted $77 \%$ (184) and injuries involving posterior segment constituted $13 \%(31)$ and that both anterior segment and posterior segment injuries constituted $11 \%(26)$. The nature of the injury differed in different age groups. Visual prognosis was better in patients who presented early and underwent appropriate treatment.

Conclusion: Educating community regarding safe riding practices, use of preventive measures, strict implementation of the traffic rules and avoiding alcohol while driving will reduce the incidence of Road traffic accidents and prevent ocular morbidity. Preventive ophthalmology plays a crucial role in educating the industrial workers to use the protective googles during their work.
\end{abstract}

Keywords: Ocular trauma, Preventive measures, Public awareness, Road traffic accidents, Workplace injury.

\section{Introduction}

The eye is the most sensitive and delicate organ. Injuries to the eye can lead to significant morbidity resulting in considerable economic losses to the individual, their families and to the nation. In addition to it, there occurs profound social implications, loss of man hours and rehabilitation for the affected. ${ }^{1}$ Ocular injuries can occur during work, slip and fall, RTA, assault and during sports activity. Therefore, there is a great need for more active interest in the prevention of eye injuries by creating public awareness all over the globe. A wider understanding of the risk factors can help us to conduct campaigns and educating the public which in turn help in the reduction of incidence of ocular trauma. Ocular trauma is regarded as one of the most important cause for the preventable blindness in the world. ${ }^{2}$ It may involve the eyelid, eyelashes, conjunctiva, cornea, sclera, iris, ocular muscles, orbital wall, lacrimal apparatus. It can also lead to vitreous haemorrhage, vitreous loss, traumatic cataract, retinal detachment, choroidal rupture, optic nerve avulsion or rupture globe. ${ }^{3}$ The analysis of this study involves recording of nature and extent of ocular injury followed by complex examination of injured eye. The patients were followed up for 12 weeks post trauma. The aim of this study is to identify the profile of ocular injuries and its sequelae that came to our hospital.

\section{Materials and Methods \\ Study}

A one- year prospective interventional hospital-based survey was carried on 240 cases of eye injury attending our hospital from January 2018 to January 2019.

\section{Inclusion criteria}

Patients with history of injury to the orbit and periorbital region in all age groups.

\section{Exclusion criteria}

Patient with pre -existing eye disease and the visual loss was secondary to the same.

A detailed history regarding the demographic data, causes, mechanism and nature and place of injury, type of vehicle and the speed at which accident occurred, use of precautionary measures such as seat belts, helmets, influence under alcohol were taken. History of pre-existing refractive errors and established eye disease. Old RTA were taken. Medical and surgical history noted. Visual acuity was taken by Snellen chart and colour vision by Ishihara chart. A detailed examination of the anterior segment by the slit lamp, pupillary response was noted and fundus examination was done by $90 \mathrm{D}$ and indirect ophthalmoscope. X-ray imaging, CT and B scan ultrasonography was done as need based. All the subjects were followed for 12 weeks from the day of presentation. Best corrected visual acuity was taken at the time of presentation and at the end of 3 months.

\footnotetext{
*Corresponding Author: Sheetal, Dept. of Ophthalmology, Saveetha Medical College, Chennai, Tamil Nadu, India Email: sheetalrjkmr@gmail.com http://doi.org/10.18231/j.ijooo.2019.033
} 


\section{Result}

Table 1: Type of Vehicle Involved

\begin{tabular}{|l|c|c|}
\hline Type of vehicle & $\begin{array}{c}\text { No of } \\
\text { Vehicles }\end{array}$ & In Percentage\% \\
\hline 2 WHEELER & 125 & $50 \%$ \\
\hline 3 WHEELER & 40 & $16 \%$ \\
\hline 4 WHEELER & 60 & $24 \%$ \\
\hline PEDESTRIANS & 25 & $10 \%$ \\
\hline
\end{tabular}

Table 2: Visual acuity recorded at the time of presentation and after 12 weeks

\begin{tabular}{|c|c|c|}
\hline Visual acuity & $\begin{array}{c}\text { At the time of } \\
\text { presentation }\end{array}$ & $\begin{array}{c}\text { After 12 weeks } \\
\text { of trauma }\end{array}$ \\
\hline $6 / 6-6 / 12$ & $144(60 \%)$ & $180(75 \%)$ \\
\hline $6 / 18-6 / 36$ & $43(18 \%)$ & $26(11 \%)$ \\
\hline $6 / 60-3 / 60$ & $24(10 \%)$ & $12(5 \%)$ \\
\hline$<3 / 60$ & $19(8 \%)$ & $12(5 \%)$ \\
\hline $\begin{array}{c}\text { No Perception of } \\
\text { Light }\end{array}$ & $9(4 \%)$ & $9(4 \%)$ \\
\hline \multicolumn{2}{|c|}{} \\
\hline
\end{tabular}

Table 2: Time of presentation

\begin{tabular}{|c|c|}
\hline$<6$ HOURS & $96(40 \%)$ \\
\hline 6-24 HOURS & $86(36 \%)$ \\
\hline 1-3 DAYS & $33(14 \%)$ \\
\hline 4-7 DAYS & $16(7 \%)$ \\
\hline$>1$ WEEK & $7(3 \%)$ \\
\hline
\end{tabular}

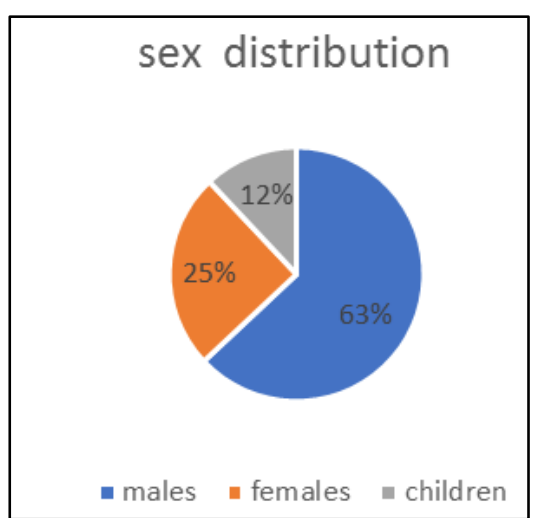

Fig. 1

Table 3: Cause of the injury

\begin{tabular}{|c|c|c|}
\hline Activity & $\begin{array}{c}\text { No. of eyes } \\
\text { involved }\end{array}$ & Percentage\% \\
\hline RTA & 105 & $21.8 \%$ \\
\hline Work place injury & 68 & $14.1 \%$ \\
\hline Sports & 59 & $12.2 \%$ \\
\hline Slip and fall & 46 & $9.5 \%$ \\
\hline Chemical injury & 43 & $8.9 \%$ \\
\hline Stick injury & 29 & $6 \%$ \\
\hline Fire crackers & 17 & $3.5 \%$ \\
\hline Assault & 12 & $2.5 \%$ \\
\hline Others & 5 & $1 \%$ \\
\hline Total & 384 & $80 \%$ \\
\hline
\end{tabular}

Table 3: Nature of eye injuries

\begin{tabular}{|c|c|}
\hline Closed globe injury & Number (Percentage) \\
\hline $\begin{array}{l}\text { Eye brow } \\
\text { Contusion } \\
\text { Laceration }\end{array}$ & $\begin{array}{c}50(21 \%) \\
21(9 \%)\end{array}$ \\
\hline $\begin{array}{c}\text { Eyelids } \\
\text { Contusion } \\
\text { Laceration } \\
\text { Matting of eyelashes }\end{array}$ & $\begin{array}{c}31(13 \%) \\
12(5 \%) \\
7(3 \%) \\
\end{array}$ \\
\hline $\begin{array}{c}\text { Conjunctiva } \\
\text { SCH } \\
\text { Chemosis } \\
\text { Phacocele } \\
\text { conjunctivitis }\end{array}$ & $\begin{array}{c}74(31 \%) \\
12(5 \%) \\
1(0.4 \%) \\
4(2 \%)\end{array}$ \\
\hline $\begin{array}{c}\text { Cornea } \\
\text { FB } \\
\text { abrasion } \\
\text { Laceration }\end{array}$ & $\begin{array}{c}36(15 \%) \\
7(3 \%)\end{array}$ \\
\hline $\begin{array}{c}\text { Anterior chamber } \\
\text { Traumatic uveitis } \\
\text { Hyphema }\end{array}$ & $\begin{array}{l}45(19 \%) \\
26(11 \%)\end{array}$ \\
\hline Iridodialysis & $24(10 \%)$ \\
\hline $\begin{array}{c}\text { Lens } \\
\text { Dislocation } \\
\text { subluxation } \\
\end{array}$ & $\begin{array}{l}17(7 \%) \\
17(7 \%)\end{array}$ \\
\hline $\begin{array}{c}\text { Sclera } \\
\text { Laceration }\end{array}$ & $12(5 \%)$ \\
\hline $\begin{array}{c}\text { Retina } \\
\text { Commotion retinae } \\
\text { Detachment }\end{array}$ & $\begin{array}{c}33(14 \%) \\
17(7 \%)\end{array}$ \\
\hline Open globe injury & Percentage \\
\hline Rupture & $2(1 \%)$ \\
\hline $\begin{array}{c}\text { Orbit wall fractures } \\
\text { Medial wall } \\
\text { Lateral wall } \\
\text { Roof } \\
\text { Floor }\end{array}$ & $\begin{array}{l}96(40 \%) \\
43(18 \%) \\
26(11 \%) \\
45(19 \%)\end{array}$ \\
\hline
\end{tabular}

The incidence of the eye injury was inversely proportional to the age group. Males were more affected than the females and children. The most common cause of eye injury varied according to the age group. Elderly people sustained eye injuries due to slip and fall. Teens sustained injuries due to RTA, sports and work place injury. Children were more prone to assault and fire cracker injury. Infants and toddlers sustained injury due to accidental injury by hand of the guardians and slip and fall injuries on their attempts for adventurous activities. The most common cause among all was the RTA accounting for $21.8 \%$ (105) to sustain injury from periorbital contusion to globe rupture. Among RTA, two wheelers accounted for the maximum injury contributing $50 \%$. This was followed by industrial work place injury which accounted for $14.1 \%$ (68) in the form of fall of metal burr in the eyes to corneal epithelial defects secondary to chemical injury and welding burns. The most common chemical injury was due to alkali than acid. 
Chemical injury also occurred at home due to dish washing agents and kerosene. A small percentage 1\% (3) of the people were farmers who sustained injury due to plant extracts and who sustained injury due to traditional eye medications like castor oil. The manifestations of eye trauma are tabulated in table 3. Closed globe injuries were more than open globe injuries. Majority of them presented within 6 hours of trauma and visual prognosis was better in the patients who presented to us at the earliest. During the final follow up over 75\% (180) of eyes had BCVA upto $6 / 12,11 \%$ (26) had upto $6 / 36,4 \%$ (9) of the eyes had no Perception of light due to Retinal detachment and globe rupture. Two patients of all underwent enucleation due to rupture globe. One eye developed phthisis.

\section{Conclusion}

Ocular injuries in RTA constitute a major cause of visual morbidity worldwide with significant economic impact. Ocular injuries are most common in major trauma. Therefore, eyes are to be examined specifically in major trauma. ${ }^{7}$ Prevention is always better than cure. It is essential to take steps to prevent RTA and thereby reducing the ocular morbidity and mortality. ${ }^{5}$ The incidence of head and eye injuries were less in those who took precautionary measures like helmet and seat belts. The incidence of chemical injury, welding burns and fall of metal burr on the cornea as well as IOFB can be reduced if the awareness is promoted among the industrial workers regarding the use of protective glasses. ${ }^{14}$ The analysis showed that in younger children the handler related injuries, household object injuries and accidental slip and fall were more common whereas in older children sports and outdoor injuries were more. ${ }^{12}$ Boys were more injured than girls. In a few the trauma lead to lifelong morbidity due to decreased vision, amblyopia, blindness and deformity. Most of the ocular injuries were preventable and they had occurred in unsupervised conditions. ${ }^{10}$ Therefore, there is a need for high supervision by parents and caretakers at home and school. Due to some reasons such as inaccessibility to ophthalmic services, poverty and ignorance of consequences, some people after sustaining ocular injury engage in instillation of harmful and traditional eye medication. ${ }^{13}$ Hence there occurs the need to create awareness among the public regarding the side effects of these harmful traditional eye treatment. Also, ocular injury when occurred should be handled urgently and methodologically if the final visual outcome is to be improve vision improved drastically in the patients with traumatic optic neuropathy who were started in injection in methyl prednisolone. Also, immediate consultation by the qualified ophthalmologist with no delay can lessen the ocular morbidity.

\section{Source of Funding}

None.

\section{Conflict of Interest}

None.

\section{Reference}

1. Klopfer J, Tielsch JM, Vitale S, See LC, Canner JK. Ocular trauma in the United States: eye injuries resulting in hospitalization, 1984 through 1987. Arch Ophthalmol 1992;110(6):838-42.

2. El Shtewi M, Shishko MN, Purohit GK. Road traffic accidents and ocular trauma: experience at Tripoli eye hospital, Libya. Comm Eye Health 1999;12(29):11.

3. Hassan KM, Waris SA, Swamiraj SV, Hussain SA. Ocular injury pattern in the university hospital of South India. Indian J Clin Exp Ophthalmol 2017 Apr;3(2):234-8.

4. Kumarasamy R, Velpandian U, Anandan H. Visual outcome in ocular injuries in road traffic accident. Cornea 2016;12:8-33.

5. Menon L, Mani S, Mathew A.The prevalence of ocular manifestations in road traffic accidents treated at a rural tertiary care hospital in south india: a cross sectional study. Int J Res Med Sci 2017;5(10):4380-4.

6. Gahlot A, Magdum R, Singh M, Kumari P. A study of ocular trauma profile and its visual outcome in road traffic accidents. National J Med Res NJMR 2015;5(3):211-5.

7. Eye injuries in Victoria, Australia. Med J Aust 1995;162(2):648 .

8. Morley MG, Nguyen JK, Heier JS, Shingleton BJ, Pasternak JF, Bower KS et al. Blast eye injuries: a review for first responders. Disaster meKrishnaiah S, Nirmalan PK, Shamanna BR, Srinivas M, Rao GN, Thomas R.

9. Ocular trauma in a rural population of southern India: The Andhra Pradesh Eye Disease Study. Ophthalmol 2006;113(7):1159-64. dicine and public health preparedness. 2010 Jun;4(2):154-60.

10. Chua D, Wong W, Lamoureux EL, Aung T, Saw SM, Wong TY. The prevalence and risk factors of ocular trauma: the Singapore Indian eye study. Ophthalmic Epidemiol 2011;18(6):281-7.

11. Gupta N, Tandon R, Gupta SK, Sreenivas V, Vashist P. Burden of corneal blindness in India. Indian J Comm Med official publication Indian Ass Prev Soc Med 2013;38(4):198.

12. Gothwal VK, Adolph S, Jalali S, Naduvilath TJ. Demography and prognostic factors of ocular injuries in South India. Aust New Zealand J Ophthalmol 1999;27(5):318-25.

13. Ajite KO, Fadamiro OC. Prevalence of harmful/traditional medication use in traumatic eye injury. Global J Health Sci 20131;5(4):55

14. Adams JS, Raju R, Solomon V, Samuel P, Dutta AK, Rose JS, Tharyan P. Increasing compliance with protective eyewear to reduce ocular injuries in stone-quarry workers in Tamil Nadu, India: a pragmatic, cluster randomised trial of a single education session versus an enhanced education package delivered over six months. Injury 2013;44(1):118-25.

15. Biswas J, Saha I, Das D, Bandyopadhyay S, Ray B, Biswas G. Ocular morbidity among children at a tertiary eye care hospital in Kolkata, West Bengal. Indian $J$ Public Health 2012;56(4):293.

16. Kumar SG, Dharanipriya A. Prevalence and pattern of occupational injuries at workplace among welders in coastal south India. Indian J Occup Environ Med 2014;18(3):135.

How to cite this article: Anuradha, Sheetal, Prevalence of ocular injuries in a tertiary care hospital, Int J Ocul Oncol Oculoplasty 2019;5(3):130-2. 